\title{
Faktor Kecerdasan Pelbagai dalam Pembentukan Profil Remaja
}

\author{
SITI RAHAYAH ARIFFIN \\ ROSENI ARIFFIN \\ ARBAIYAH MD ZIN \\ NIK NORALHUDA NIK MOHAMED* \\ Universiti Kebangsaan Malaysia \\ niksmkp1@yahoo.com*
}

\section{ABSTRAK}

Kajian ini bertujuan mengenal pasti sumbangan faktor-faktor kecerdasan pelbagai (KP) terhadap lapan kecerdasan pelbagai yang dipelopori oleh Gardner. Kajian ini juga bertujuan meninjau perbezaan faktor-faktor kecerdasan pelbagai berdasarkan jantina, bangsa, kategori sekolah, aliran dan SES (Social Economic Status). Kajian ini telah dijalankan secara tinjauan dan dianalisa secara kuantitatif ke atas 511 pelajar dengan menggunakan instrumen MyMICA 2006 (Malaysian Multiple Intelligence Check list for Adult 2006). Analisis regresi linear menunjukkan kecerdasan Visual Ruang memberi sumbangan paling tinggi iaitu $97.8 \%$ terhadap kecerdasan Logik Matematik manakala kecerdasan Verbal Linguistik pula memberi sumbangan paling rendah iaitu $22.2 \%$ terhadap kecerdasan Muzik. Melalui analisis MANOVA, antara dapatan yang diperoleh ialah terdapat perbezaan yang signifikan berdasarkan kategori sekolah dalam dua kecerdasan pelbagai iaitu Verbal Linguistik $(\mathrm{F}=25.11, \mathrm{p}<0.01)$ dan Intrapersonal $(\mathrm{F}=14.85$, $\mathrm{p}<0.01)$. Terdapat juga perbezaan yang signifikan antara pelajar Melayu dan bukan Melayu pada dua kecerdasan pelbagai iaitu Muzik $(\mathrm{F}=12.82, \mathrm{p}<0.01)$ dan Kinestatik $(\mathrm{F}=9.58, \mathrm{p}<0.01)$. Implikasi kajian menunjukkan guru dan pentadbir sekolah perlu peka terhadap kecerdasan pelbagai yang berbeza bagi setiap individu pelajar. Guru seharusnya mengguna sepenuhnya kemudahan prasarana sekolah untuk mencungkil kecerdasan ini bagi memaksimumkan prestasi pelajar. 


\begin{abstract}
Purpose - This study aimed to identify factors of multiple intelligences (MI) contributing on the eight multiple intelligence pioneered by Gardner. The study also aims to explore the different factors of multiple intelligences based on gender, race, school category, stream and SES (Social Economic Status).
\end{abstract}

Method - This quantitative and survey study was conducted on 511 students using the MyMICA 2006 (Malaysian Multiple Intelligence Check list for Adult 2006) instrument.

Findings - Linear regression analysis showed that the contribution of Visual Space intelligence factor on Mathematical Logic intelligence is the highest (97.8\%) and the contribution of Verbal Linguistics intelligence factor on Music intelligence is the lowest $(22.2 \%)$. MANOVA analysis showed that there is a significant difference between Verbal Linguistics intelligence $(\mathrm{F}=25.11, \mathrm{p}<$ $0.01)$ and Intrapersonal intelligence $(\mathrm{F}=14.85, \mathrm{p}<0.01)$ based on two different school categories. There is also a significant difference between Malay and non-Malay students regarding two intelligences, Musical $(\mathrm{F}=12.82, \mathrm{p}<0.01)$ and Kinesthetic $(\mathrm{F}=9.58, \mathrm{p}<0.01)$.

Significance - This study also shows that teachers and school - administrators should be sensitive to the multiple intelligences of

each individual student. Teachers and schools' environment should nurture these intelligences to maximize students' performance for all subjects.

Keywords: Multiple intelligence, MyMICA 2006 (Malaysian Multiple Intelligence Check list for Adult 2006), teenager, gender, race, school category, stream, SES (Social Economic Status).

\title{
PENGENALAN
}

Menurut Spearman (1904, 1927), konsep asal kecerdasan adalah g-faktor iaitu kecerdasan seseorang individu disebabkan oleh faktor genetik atau keturunan. Kini, g-faktor tidak boleh menggambarkan kecerdasan seseorang individu secara holistik, malah konsep ini terus berkembang kepada s-faktor iaitu kecerdasan seseorang individu hanya disebabkan oleh satu faktor sahaja. 
Pada tahun 1980-an, Howard Gardner telah mengemukakan suatu teori iaitu Teori Kecerdasan Pelbagai bahawa kecerdasan manusia bukan hanya tertumpu oleh satu faktor sahaja malah kecerdasan itu boleh berkembang sama ada melalui persekitaran, pendidikan dan pengalaman. Menurut beliau lagi, setiap kecerdasan adalah berasingan dan tidak saling bergantung, kerana seseorang individu mungkin cemerlang dalam sesuatu bidang kemahiran tetapi lemah dalam bidang kecerdasan yang lain.

Berlandaskan Teori Kecerdasan Pelbagai yang diasaskan oleh Howard Gardner (1983, 1993), faktor ini membuktikan bahawa semua individu mempunyai tujuh jenis kecerdasan iaitu Verbal Linguistik (VL), Logik Matematik (LM), Visual Ruang (VR), Kinestatik (KI), Muzik (MZ), Interpersonal (IE), dan Intrapersonal (IA). Beliau turut menambah kecerdasan kelapan iaitu kecerdasan Naturalis (NA) dalam teori ini. Gardner mentakrifkan kecerdasan sebagai "the capacity to solve problems or fashion products which are valued in one or more cultural settings" (Gardner \& Hatch, 1989: 5).

Menurut Howard Gardner (1983), setiap faktor-faktor kecerdasan pelbagai memiliki maksud tersendiri. Kecerdasan Verbal Linguistik (VL) ialah kebolehan dalam pertuturan, penulisan, mengingat maklumat, meyakini orang lain dan berkomunikasi tentang bahasa itu sendiri. Kecerdasan Logik Matematik (LM) pula adalah kebolehan menggunakan nombor secara berkesan, bijak berhujah, memahami kelompok nombor asas, prinsip sebab-akibat serta kebolehan menjangka suatu peristiwa. Kecerdasan Visual Ruang (VR) bererti kebolehan mengesan dan menggambarkan bentuk, ruang, warna dan garisan serta mempersembahkan idea visual dan ruang secara grafik.

Kecerdasan Kinestatik (KI) adalah kebolehan menggunakan anggota badan untuk menyatakan idea, perasaan dan menyelesaikan masalah termasuklah kemahiran fizikal seperti koordinasi, keanjalan, kepantasan dan keseimbangan. Kecerdasan Muzik (MZ) adalah kebolehan mengesan irama dan lagu, mengenal, membeza atau mengubah rentak dan tempo dalam melodi. Kecerdasan Interpersonal (IE) pula membawa maksud kebolehan memahami perasaan, motivasi, tabiat atau hasrat orang lain dan kemahiran bertindak secara berkesan terhadap orang lain secara praktikal. Kecerdasan Intrapersonal (IA) merupakan kebolehan memahami diri sendiri dari segi kekuatan, kelemahan, hasrat atau kehendak, kemahiran yang sama atau berbeza dengan orang lain serta mampu 
menangani perasaan, beradab sopan serta mengawal kemarahan atau kesedihan diri. Kecerdasan terakhir iaitu Kecerdasan Naturalis (NA) adalah kebolehan mengenali dan mengklasifikasi tumbuhtumbuhan, galian, dan binatang, termasuk rumput dan batu-batuan, pelbagai flora dan fauna serta kebolehan mengenali artifak budaya dari segi pakaian dan makanan (Gardner, 1993).

Hari ini, masyarakat mantafsirkan pelajar cemerlang adalah mereka yang mendapat 'A' dalam peperiksaan. Tafsiran itu membawa kepada kekeliruan apabila masyarakat mendefinisikan pelajar yang tidak mendapat pencapaian tinggi atau cemerlang dalam peperiksaan awam sebagai gagal, dan kegagalan itu dianggap sebagai kegagalan sepanjang hayat (Ibrahim, 2003). Kekeliruan yang berlanjutan ini menyebabkan masyarakat berpegang kepada stigma, di mana pencapaian dan kejayaan persekolahan sebagai kredibiliti kejayaan di tempat kerja atau dalam kehidupan (Ibrahim, 2003). Kesannya, sebilangan pelajar yang tercicir dan terpinggir boleh mendatangkan masalah kepada negara.

Maka, kita mesti berganjak kepada satu fahaman bahawa semua manusia berpotensi dan mampu menonjolkan potensi mereka dalam pelbagai bentuk dan keadaan. Kegagalan dalam peperiksaan bukan bererti mereka langsung tidak mempunyai kemahiran. Hal ini kerana pencapaian dalam konteks sekarang merujuk kepada kecenderungan seseorang dalam mengingati fakta serta menyelesaikan masalah Logik Matematik, lisan dan bahasa semata-mata seperti yang terdapat dalam ujian kecerdasan (Ujian IQ). Fokus sistem persekolahan dan peperiksaan lebih tertumpu kepada dua domain kecerdasan sahaja iaitu Verbal Linguistik dan Logik Matematik (Gardner, 1993; Teele, 1997; Pusat Perkembangan Kurikulum (PPK), KPM, 2002; Hanizah, Siti Rahayah \& Ruhizan, 2006). Sistem pentaksiran di Malaysia juga menekankan penguasaan VL dan LM kerana kedua-dua bidang ini adalah kecerdasan intelek (IQ) (Siti Rahayah, T. Subahan, Norasmah \& Ibrahim, 2004).

Siti Rahayah et al. (2004) juga menyatakan bahawa penekanan dalam pentaksiran tersebut tidak menjadi kesalahan tetapi sewajarnya diberikan juga penekanan kepada kecerdasan lain bagi melahirkan seseorang individu yang berjaya dan mampu bersaing. Mereka yang gagal dan tercicir itu mungkin mempunyai kecenderungan dan kemahiran dalam domain lain seperti Kecerdasan Visual Ruang, Muzik, Kinestatik, Interpersonal dan Intrapersonal yang kurang ditegaskan dalam sistem pendidikan. Menurut Siti Rahayah et al. (2004) lagi, kecerdasan pelbagai dipercayai wujud dalam diri setiap 
individu maka ia perlu ditonjolkan, digilap dan digunakan untuk menyelesaikan masalah dalam kehidupan manusia. Justeru itu, dalam usaha mendidik dan menyediakan alam persekitaran yang menggalakkan, kecerdasan pelbagai adalah amat penting kerana perkembangan potensi individu yang seimbang dari segi jasmani, emosi, rohani dan intelek (JERI) berdasarkan Falsafah Pendidikan Negara Malaysia perlu dititikberatkan.

Kajian lepas oleh Siti Rahayah, Roseni dan Hafsa (2008) telah mengenal pasti faktor kecerdasan pelbagai yang menyumbang kepada kecerdasan Verbal Linguistik dan Logik Matematik. Seterusnya, kajian ke atas profil remaja pula mendapati bahawa skor min tertinggi adalah pada kecerdasan Kerohanian, diikuti kecerdasan Intrapersonal, kecerdasan Logik Matematik dan kecerdasan Interpersonal (Siti Rahayah et al., 2008). Hal ini jelas menunjukkan bahawa seseorang remaja itu mempunyai lebih daripada dua kecerdasan tradisi iaitu kecerdasan Verbal Linguistik dan Logik Matematik.

Kajian berdasarkan jantina dalam kebanyakan kajian kecerdasan pelbagai mendapati terdapatnya perbezaan yang signifikan antara pelajar lelaki dan pelajar perempuan (Harms, 1992; Sook, 1996; Franzen, 1999; Hsoe dan Tang, 2002; Chan, 2006; Siti Rahayah \& Nor Azaheen, 2009; Rodiah, Siti Rahayah \& Noriah, 2009). Pelajar Melayu didapati mempunyai tahap pemikiran kritikal (kecerdasan Verbal Linguistik dan kecerdasan Logik Matematik) yang tinggi dalam konstruk melibatkan reasoning, disposition dan assumption manakala pelajar berbangsa Cina dan India pula didapati lebih terserlah dalam konstruk analitikal dan logikal (Siti Rahayah \& Nor Azaheen, 2009).

Kajian Meers dan Wiseman (2002) mentaksirkan kecerdasan pelbagai dalam kalangan pelajar berdasarkan aliran mendapati terdapatnya perbezaan yang signifikan antara pelajar aliran Sains dan Bukan Sains (Hyun, 2001; Siti Rahayah \& Nor Azaheen, 2009). Sekolah berasrama adalah antara pelajar yang berpencapaian tinggi dalam peperiksaan awam UPSR dan PMR. Kebiasaannya pelajar yang berpencapaian tinggi dalam peperiksaan awam ini memiliki pemikiran kritikal (kecerdasan Verbal Linguistik dan kecerdasan Logik Matematik) yang tinggi (Siti Rahayah \& Nor Azaheen, 2009). Namun begitu, pelajar dari sekolah berasrama yang tinggi dari segi pencapaian akademik juga memiliki kecerdasan Muzik dan Kecerdasan Kinestatik yang rendah (Siti Rahayah et al., 2004). Terdapat perbezaan yang signifikan dalam kajian berdasarkan 
sekolah luar bandar dan bandar (Siti Rohayah \& Nor Azaheen, 2009), ekoran daripada sekolah luar bandar yang mempunyai tahap kemudahan terhad serta mempengaruhi proses pengajaran dan pembelajaran. Tambahan lagi, pelajar di sekolah luar bandar adalah terdiri daripada keluarga yang mempunyai status sosio ekonomi rendah. Keluarga yang mempunyai status sosio ekonomi kukuh menunjukkan kemahiran pemikiran kritikal (kecerdasan Verbal Linguistik dan kecerdasan Logik Matematik) lebih kukuh (Siti Rahayah, Roseni, Siti Fazriah dan Akbariah, 2006). Ekoran dari itu juga, perbezaan kecerdasan pelbagai antara status sosio ekonomi dikaji. Maka, kajian ini dijalankan bertujuan mengenal pasti adakah wujudnya perbezaan faktor-faktor kecerdasan pelbagai dalam kalangan pelajar berdasarkan jantina, bangsa, kategori sekolah, aliran dan SES (Social Economic Status).

\section{METODOLOGI}

Kajian tinjauan ini memilih sampel seramai 511 pelajar tingkatan empat dengan menggunakan Jadual Penentuan Sampel Reaves (1992). Kaedah tinjauan dengan pemilihan sampel secara rawak berstrata digunakan mengikut jantina, bangsa, kategori sekolah, aliran dan SES. Data dianalisis dengan menggunakan statistik deskriptif (profiling) dan statistik inferensi. Regresi Linear digunakan bagi mengenal pasti sumbangan dan perkaitan antara lapan faktor kecerdasan pelbagai yang dikaji. Manakala MANOVA pula digunakan untuk mengenal pasti perbezaan kecerdasan pelbagai berdasarkan jantina, aliran, kategori sekolah, bangsa dan SES. Instrumen kajian menggunakan soal selidik MyMICA (Siti Rahayah, Noriah \& Abdul Ghafur, 2006) dengan 119 item.

Sampel kajian seramai 511 pelajar tingkatan empat berumur di antara 16 hingga 17 tahun dari sekolah dalam satu daerah di Selangor yang terdiri daripada $287(56.20 \%)$ responden lelaki dan 224 (43.80\%) responden perempuan. Manakala responden Melayu seramai 296 (57.90\%), dan bukan Melayu seramai 215 (42.10\%). Dari segi kategori sekolah, 299 (58.50\%) pelajar adalah dari sekolah harian manakala $212(41.50 \%)$ pelajar adalah dari sekolah berasrama. Pecahan pelajar berdasarkan aliran menunjukkan pelajar dari aliran sains seramai $303(59.30 \%)$ dan aliran bukan sains seramai 208 $(40.70 \%)$. Pelajar dari SES tinggi seramai $225(44.00 \%)$ dan pelajar dari SES rendah seramai $286(55.00 \%)$. 


\section{DAPATAN KAJIAN}

Kebolehpercayaan keseluruhan instrumen dengan 119 item ditunjukkan oleh nilai Alfa Cronbach ialah 0.96. Item yang terlibat dalam kecerdasan Muzik ialah item bernombor satu hingga 14. Manakala, item nombor 15 hingga 27 mengukur kecerdasan Kinestetik, item nombor 28 hingga 44 untuk mengukur kecerdasan Logik Matematik, item nombor 45 hingga 59 mengukur kecerdasan Visual Ruang, item nombor 60 hingga 79 mengukur kecerdasan Verbal Linguistik, item nombor 80 hingga 97 mengukur kecerdasan Interpersonal, item nombor 98 hingga 106 mengukur kecerdasan Intrapersonal dan item nombor 107 hingga 119 mengukur kecerdasan Naturalis. Nilai kebolehpercayaan Alfa Cronbach bagi setiap faktor kecerdasan pelbagai pula ditunjukkan dalam Jadual 1 adalah antara 0.8 hingga 0.90 iaitu mempunyai kebolepercayaan tinggi, ini adalah kerana pekali alfa melebihi 0.7 dikatakan mempunyai kebolepercayaan tinggi (Pallant, 2007).

Jadual 1

Nilai Kebolehpercayaan Alfa Cronbach

\begin{tabular}{lcc}
\hline \multicolumn{1}{c}{ Faktor Kecerdasan } & n item & Nilai Alfa Cronbach \\
\hline Muzik (MZ) & 14 & 0.85 \\
Kinestetik (KI) & 13 & 0.78 \\
Logik Matematik (LM) & 17 & 0.85 \\
Visual Ruang (VR) & 15 & 0.82 \\
Verbal Linguistik (VL) & 10 & 0.89 \\
Interpersonal (IE) & 18 & 0.88 \\
Intrapersonal (IA) & 19 & 0.82 \\
Naturalis (NA) & 13 & 0.90 \\
Jumlah (Keseluruhan) & 119 & 0.96 \\
\hline
\end{tabular}

Jadual 2 menunjukkan sejauh manakah faktor kecerdasan pelbagai penyumbang kepada lapan faktor kecerdasan. Dalam faktor Logik Matematik menunjukkan sumbangan sebanyak $97.80 \%(\beta=0.54, \mathrm{t}=$ 
15.37, $\mathrm{p}=0.00$ dan $\mathrm{R}^{2}=0.98$ ) oleh faktor kecerdasan Visual Ruang. Dalam faktor Verbal Linguistik menunjukkan sumbangan sebanyak $50.20 \%\left(\beta=0.71, t=22.59, p=0.00\right.$ dan $\left.R^{2}=0.50\right)$ oleh faktor kecerdasan Interpersonal. Dalam faktor kecerdasan Intrapersonal menunjukkan sumbangan sebanyak $44.50 \%(\beta=0.43, \mathrm{t}=9.30, \mathrm{p}$ $=0.00$ dan $\left.\mathrm{R}^{2}=0.45\right)$ oleh faktor kecerdasan Interpersonal. Dalam faktor Visual Ruang menunjukkan sumbangan sebanyak $44.10 \%$ ( $\beta$ $=0.44, \mathrm{t}=11.14, \mathrm{p}=0.00$ dan $\mathrm{R}^{2}=0.44$ ) oleh faktor kecerdasan Logik Matematik. Dalam faktor kecerdasan Interpersonal menunjukkan sumbangan sebanyak $43.90 \%(\beta=0.80, t=21.95, p=0.00$ dan $\left.\mathrm{R}^{2}=0.44\right)$ oleh faktor kecerdasan Intrapersonal. Dalam faktor kecerdasan Naturalis menunjukkan sumbangan sebanyak $31.80 \%$ $\left(\beta=0.46, t=11.58, p=0.00\right.$ dan $\left.R^{2}=0.32\right)$ oleh faktor kecerdasan Visual Ruang. Dalam faktor kecerdasan Kinestatik menunjukkan sumbangan sebanyak 27.90\% $\left(\beta=0.25, \mathrm{t}=5.09, \mathrm{p}=0.00\right.$ dan $\mathrm{R}^{2}$ $=0.28$ ) oleh faktor kecerdasan Verbal Linguistik. Dalam faktor kecerdasan Muzik menunjukkan sumbangan sebanyak $22.20 \%$ ( $\beta=$ $0.30, \mathrm{t}=5.28, \mathrm{p}=0.00$ dan $\mathrm{R}^{2}=0.22$ ) oleh faktor kecerdasan Verbal Linguistik.

Jadual 2

Analisis Regresi Linear Berganda (Stepwise) bagi Meramal - Sumbangan Setiap Faktor Kecerdasan Pelbagai terhadap Kecerdasan Pelbagai

\begin{tabular}{rllllllll}
\hline Faktor KP & VR & IE & IE & LM & IA & VR & VL & VL \\
\hline
\end{tabular}

LM $\quad 97.8 \%$

VL $50.2 \%$

IA

VR $44.1 \%$

IE $43.9 \%$

NA $31.8 \%$

KI $27.9 \%$

MZ 
Jadual 3 menunjukkan min peratus bagi faktor kecerdasan pelbagai berdasarkan faktor demografi remaja. Data ini dipindahkan dan diperlihat dengan jelas menerusi graf dalam Rajah 1 hingga Rajah 6.

Jadual 3

Min Peratus Faktor Kecerdasan Pelbagai mengikut Faktor Demografi

\begin{tabular}{llcccccccc}
\hline & $\begin{array}{c}\text { Faktor } \\
\text { Demografi }\end{array}$ & \multicolumn{6}{c}{ FAKTOR KECERDASAN PELBAGAI } \\
\cline { 3 - 9 } & MZ & KI & LM & VR & VL & IE & IA & NA \\
\hline \multirow{2}{*}{ Jantina } & Lelaki & 52.00 & 52.14 & 63.94 & 64.41 & 54.58 & 64.45 & 64.02 & 56.20 \\
& Perempuan & 48.23 & 46.09 & 66.00 & 59.60 & 57.00 & 60.40 & 63.35 & 49.08 \\
Bangsa & Melayu & 49.11 & 48.86 & 61.85 & 63.09 & 53.93 & 63.44 & 63.87 & 54.36 \\
& Bukan Melayu & 52.87 & 53.32 & 63.02 & 62.65 & 57.17 & 64.47 & 64.88 & 54.98 \\
Kategori & Harian & 51.59 & 49.99 & 61.67 & 61.86 & 51.75 & 62.79 & 61.83 & 52.92 \\
Sekolah & Berasrama & 49.76 & 50.71 & 64.14 & 64.47 & 57.46 & 63.51 & 66.62 & 55.57 \\
Aliran & Sains & 51.52 & 52.00 & 65.12 & 65.24 & 56.29 & 65.45 & 65.44 & 55.61 \\
& Bukan Sains & 48.79 & 45.23 & 55.48 & 56.17 & 47.70 & 56.59 & 59.00 & 49.33 \\
SES & Tinggi & 55.73 & 52.78 & 63.59 & 63.45 & 59.99 & 66.12 & 67.35 & 57.87 \\
& Rendah & 50.00 & 53.78 & 61.38 & 61.89 & 54.36 & 62.78 & 62.44 & 52.08 \\
\hline
\end{tabular}

Rajah 1 menunjukkan secara keseluruhan pelajar-pelajar tingkatan empat mempunyai skor min peratus tinggi dalam dua faktor iaitu faktor kecerdasan Intrapersonal (63.88) dan faktor kecerdasan Interpersonal (63.00). Manakala skor min peratus terendah adalah faktor kecerdasan Kinestatik (50.49).

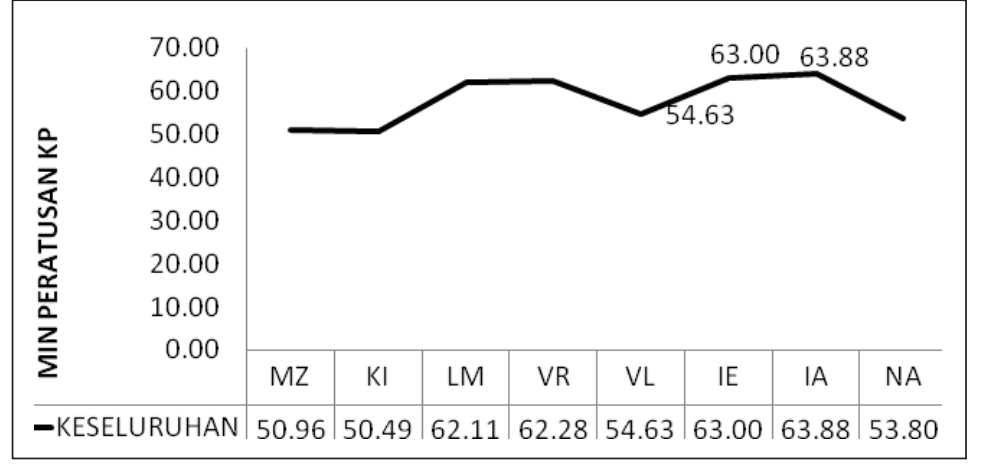

Rajah 1. Graf Profil Kecerdasan Pelbagai secara Keseluruhan 
Rajah 2 menunjukkan, skor min peratus pelajar perempuan adalah lebih baik berbanding pelajar lelaki hanya dalam dua faktor iaitu faktor kecerdasan Verbal Linguistik (57.00) dan faktor kecerdasan Logik Matematik (66.00).

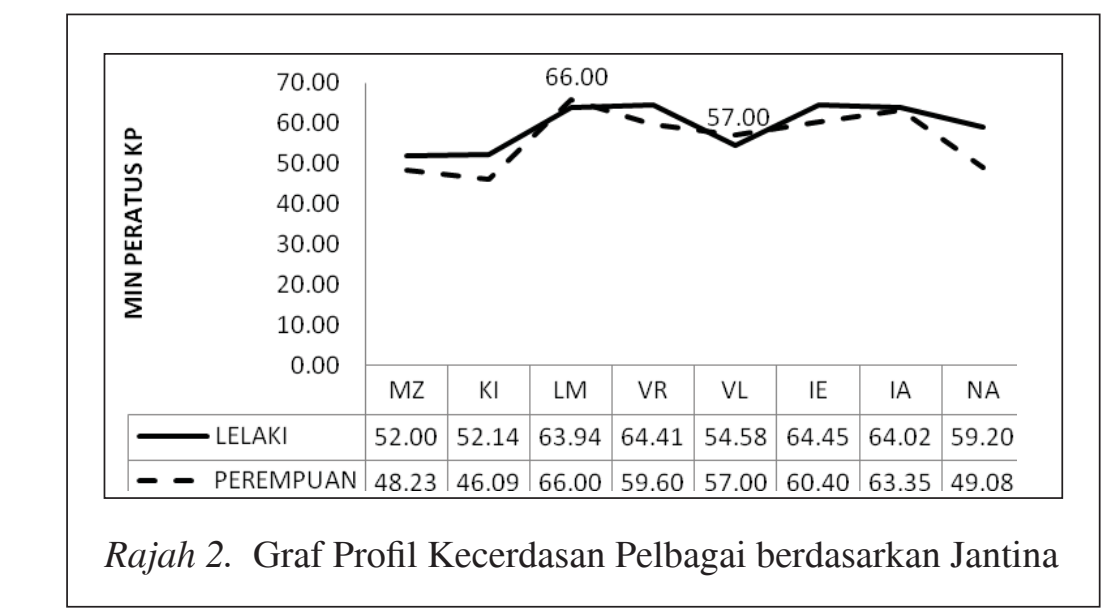

Rajah 3 menunjukkan berdasarkan bangsa, skor min peratus dalam faktor kecerdasan Visual Ruang bagi pelajar Melayu (63.09) adalah lebih tinggi daripada skor min peratus pelajar bukan Melayu (62.65).

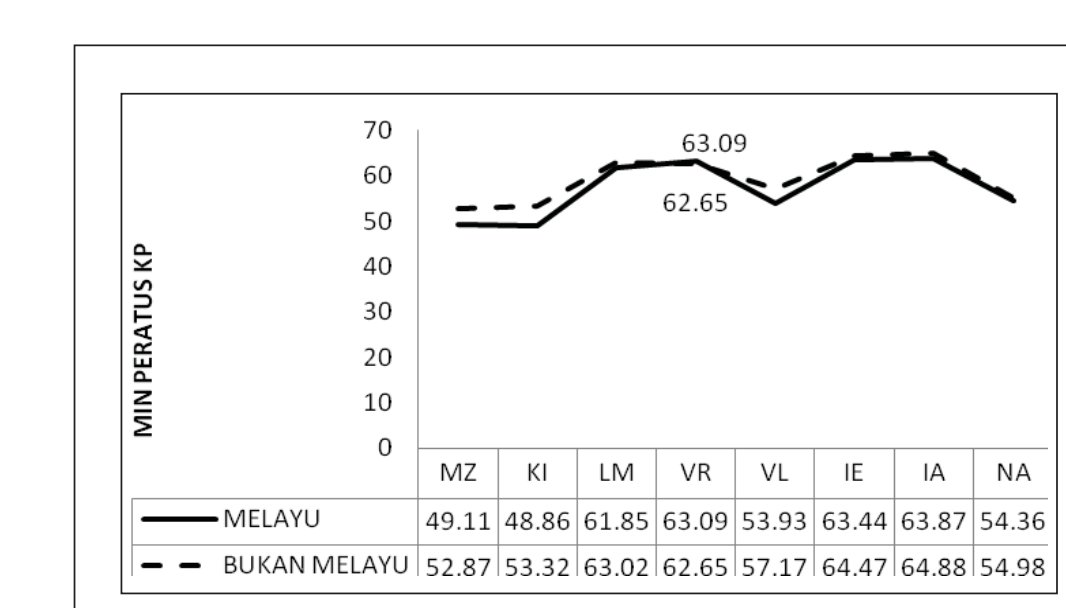

Rajah 3. Graf Profil Kecerdasan Pelbagai berdasarkan Bangsa

Rajah 4 menunjukkan berdasarkan kategori sekolah, pelajar berasrama mempunyai skor min peratus tinggi dalam semua faktor kecerdasan pelbagai kecuali faktor kecerdasan Muzik dan pelajar 
sekolah berasrama peroleh skor min peratus paling tinggi dalam kecerdasan Intrapersonal (66.62).

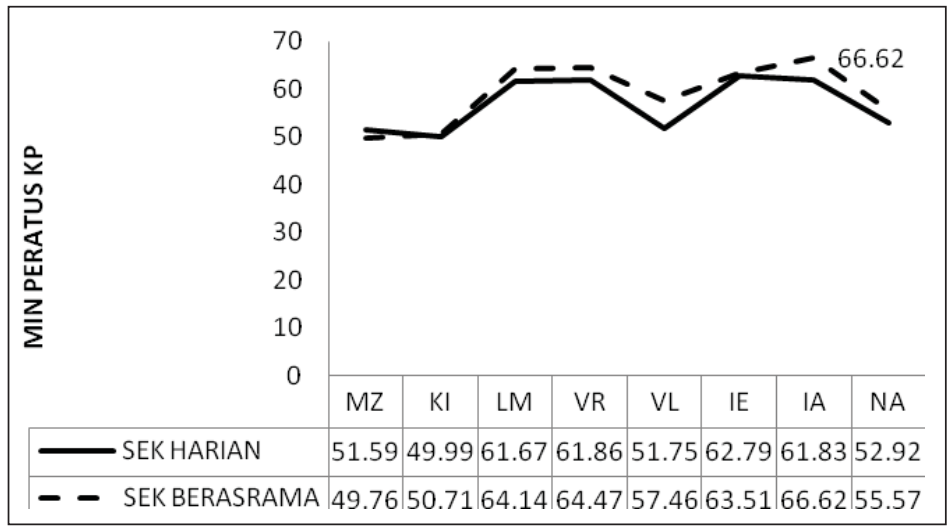

Rajah 4. Graf Profil Kecerdasan Pelbagai berdasarkan Kategori Sekolah

Rajah 5 menunjukkan pelajar aliran Sains mempunyai skor min peratus yang tinggi dalam semua kecerdasan pelbagai berbanding pelajar aliran bukan Sains. Antara skor min peratus yang tinggi adalah kecerdasan Logik Matematik (65.12), kecerdasan Visual Ruang (65.24), kecerdasan Interpersonal (65.45) dan kecerdasan Intrapersonal (65.44).

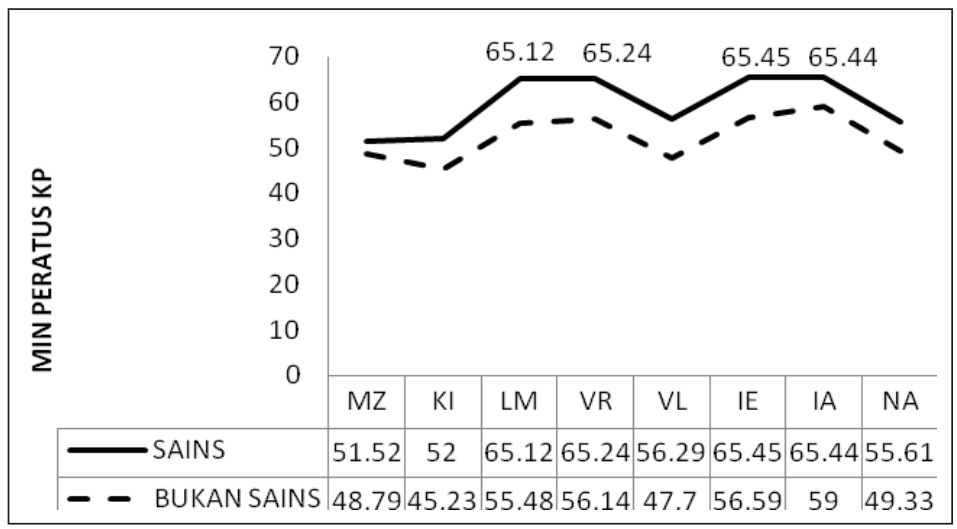

Rajah 5. Graf Profil Kecerdasan Pelbagai berdasarkan Aliran 
Rajah 6 menunjukkan pelajar dari SES rendah mempunyai skor min peratus tinggi dalam faktor kecerdasan Kinestatik (53.78) berbanding pelajar SES tinggi (52.78). Manakala pelajar SES tinggi memperoleh skor min peratus yang tinggi dalam faktor kecerdasan Intrapersonal (67.35) dan faktor kecerdasan Interpersonal (66.12).

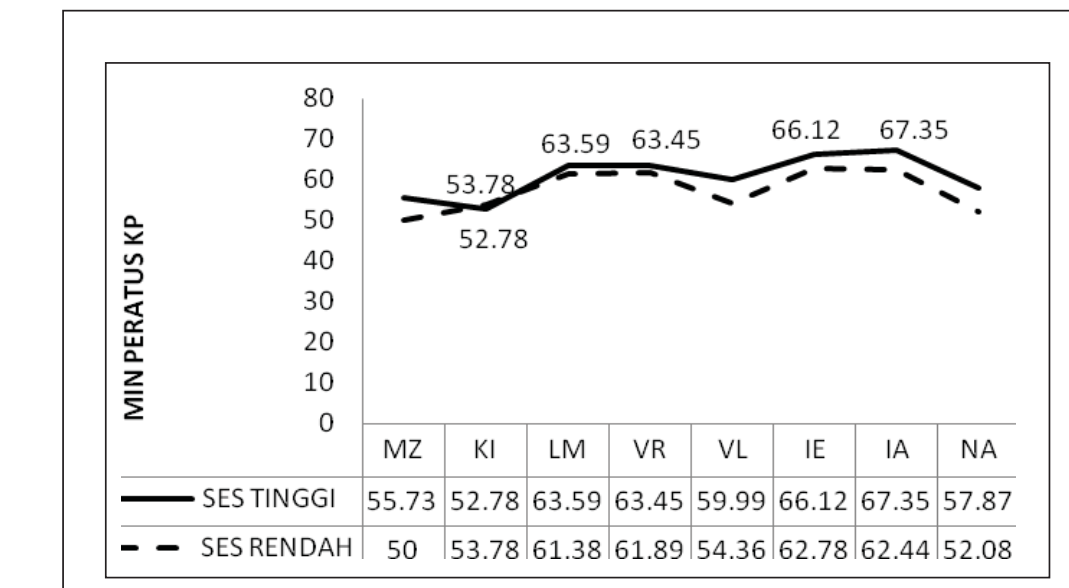

Rajah 6. Graf Profil Kecerdasan Pelbagai berdasarkan SES

Jâdual 4

Hasil Ujian Perbezaan Faktor-faktor Kecerdasan Pelbagai Berdasarkan Faktor Demografi

Faktor Demografi Nilai Wilk's Lamda $(\lambda)$ Nilai $F$ Tahap Sig. $P$

\begin{tabular}{lccc} 
Jantina & 0.89 & 7.66 & 0.00 \\
Aliran & 0.82 & 12.99 & 0.00 \\
Kategori Sekolah & 0.87 & 7.01 & 0.00 \\
Bangsa & 0.93 & 4.66 & 0.00 \\
SES & 0.91 & 6.17 & 0.00 \\
\hline
\end{tabular}

Jadual 4 menunjukkan nilai Wilk's Lamda $(\lambda)$ dan tahap signifikan dalam ujian perbezaan dalam semua lapan faktor kecerdasan 
pelbagai berdasarkan kelima-lima demografi. Terdapat perbezaan min yang signifikan dikenal pasti dalam setiap faktor kecerdasan pelbagai berdasarkan faktor demografi pelajar. Justeru, juga perbezaan min antara semua lapan kecerdasan pelbagai berdasarkan setiap demografi dikenal pasti menerusi Jadual 5 hingga Jadual 9.

Jadual 5

Faktor-faktor Kecerdasan Pelbagai Berdasarkan Jantina Menggunakan Analisis MANOVA

\begin{tabular}{lcll}
\hline \multicolumn{1}{c}{ Faktor } & F & Sig. & Eta Squared \\
\hline Muzik & 8.38 & $0.004^{*}$ & 0.017 \\
Kinestatik & 24.40 & $0.000^{*}$ & 0.047 \\
Logik Matematik & 15.53 & $0.000^{*}$ & 0.031 \\
Visual Ruang & 22.47 & $0.000^{*}$ & 0.044 \\
Verbal Linguistik & 1.29 & 0.257 & 0.003 \\
Interpersonal & 0.61 & 0.436 & 0.001 \\
Intrapersonal & 0.297 & 0.586 & 0.001 \\
Naturalis & 22.50 & $0.000^{*}$ & 0.044 \\
\hline
\end{tabular}

Jadual 5 menunjukkan terdapat perbezaan min yang signifikan dalam lima kecerdasan pelbagai iaitu kecerdasan Muzik $(F=8.38$, $p<0.01)$, kecerdasan Kinestatik $(F=24.40, p<0.01)$, kecerdasan Logik Matematik $(F=15.53, p<0.01)$, kecerdasan Visual Ruang $(F=22.47, \quad p<0.01)$ dan kecerdasan Naturalis $(F=22.50, p<0.01)$ terhadap pelajar perempuan dan pelajar lelaki. Tetapi tidak terdapat perbezaan yang signifikan dalam faktor kecerdasan Verbal Linguistik, kecerdasan Interpersonal dan kecerdasan Intrapersonal berdasarkan jantina.

Jadual 6 menunjukkan tujuh daripada lapan kecerdasan pelbagai mempunyai perbezaan min yang signifikan dan hanya kecerdasan Muzik sahaja tidak menunjukkan perbezaan signifikan yang terhadap aliran (Sains dan bukan Sains). 
Jadual 6

Faktor-faktor Kecerdasan Pelbagai Berdasarkan Aliran Menggunakan Analisis MANOVA

\begin{tabular}{lccc}
\hline \multicolumn{1}{c}{ Faktor } & $\boldsymbol{F}$ & Sig. & Eta Squared \\
\hline Muzik & 3.52 & 0.060 & 0.007 \\
Kinestatik & 26.84 & $0.000^{*}$ & 0.052 \\
Logik Matematik & 74.62 & $0.000^{*}$ & 0.132 \\
Visual Ruang & 72.03 & $0.000^{*}$ & 0.128 \\
\hline Verbal Linguistik & 43.01 & $0.000^{*}$ & 0.081 \\
Interpersonal & 24.11 & $0.000^{*}$ & 0.047 \\
Intrapersonal & 20.34 & $0.000^{*}$ & 0.040 \\
Naturalis & 14.50 & $0.000^{*}$ & 0.029 \\
\hline
\end{tabular}

Jadual 7

Faktor-faktor Kecerdasan Pelbagai Berdasarkan Kategori Sekolah Menggunakan Analisis MANOVA

\begin{tabular}{lrll}
\multicolumn{1}{c}{ Faktor } & $\boldsymbol{F}$ & Sig. & Eta Squared \\
\hline Muzik & 2.54 & 0.112 & 0.005 \\
Kinestatik & 0.29 & 0.589 & 0.001 \\
Logik Matematik & 6.11 & 0.014 & 0.012 \\
Visual Ruang & 6.98 & 0.009 & 0.014 \\
Verbal Linguistik & 25.11 & $0.000^{*}$ & 0.049 \\
Interpersonal & 5.74 & 0.017 & 0.012 \\
Intrapersonal & 14.85 & $0.000 *$ & 0.029 \\
Naturalis & 2.13 & 0.145 & 0.004 \\
\hline
\end{tabular}

Jadual 7 menunjukkan hanya kecerdasan Verbal Linguistik $(F=25.11, \quad p<0.01)$ dan kecerdasan Intrapersonal $(F=14.85$, $p<0.01)$ mempunyai perbezaan min yang signifikan terhadap kategori sekolah (sekolah harian dan sekolah berasrama). Manakala 
enam kecerdasan lain iaitu kecerdasan Muzik, Kinestatik, Logik Matemati, Visual Ruang, Interpersonal dan Naturalis tidak terdapat perbezaan yang signifikan $(p>0.01)$ berdasarkan kategori sekolah.

Jadual 8

Faktor-faktor Kecerdasan Pelbagai Berdasarkan Bangsa Menggunakan Analisis MANOVA

\begin{tabular}{lrll}
\hline \multicolumn{1}{c}{ Faktor } & F & Sig. & Eta Squared \\
\hline Muzik & 12.82 & $0.000^{*}$ & 0.025 \\
Kinestatik & 9.58 & $0.002^{*}$ & 0.019 \\
Logik Matematik & 3.56 & 0.060 & 0.007 \\
Visual Ruang & 0.19 & 0.666 & 0.000 \\
Verbal Linguistik & 0.26 & 0.612 & 0.001 \\
Interpersonal & 4.39 & 0.037 & 0.009 \\
Intrapersonal & 0.106 & 0.745 & 0.000 \\
Naturalis & 0.009 & 0.924 & 0.000 \\
\hline
\end{tabular}

Jadual 8 menunjukkan hanya kecerdasan $\operatorname{Muzik}(F=12.82, p<0.01)$ dan kecerdasan Kinestatik $(F=9.58, p<0.01)$ mempunyai perbezaan min yang signifikan terhadap bangsa (Melayu dan bukan Melayu). Manakala enam kecerdasan lain iaitu, kecerdasan Logik Matematik, Visual Ruang, Verbal Linguistik, Interpersonal, Intrapersonal dan Naturalis tidak terdapat perbezaan yang signifikan $(\mathrm{p}>0.01)$ berdasarkan bangsa.

Jadual 9 menunjukkan terdapat perbezaan min yang signifikan dalam enam kecerdasan pelbagai iaitu kecerdasan Muzik $(F=10.09$, $p<0.01)$, kecerdasan Kinestatik $(F=11.97, p<0.01)$, kecerdasan Logik Matematik $(F=22.08, p<0.01)$, kecerdasan Visual Ruang $(F=25.38, \quad p<0.01)$, kecerdasan Verbal Linguistik $(F=31.58$, $p<0.01)$ dan kecerdasan Interpersonal $(F=9.23, p<0.01)$ terhadap SES Pelajar. Manakala kecerdasan Intrapersonal dan kecerdasan Naturalis, tidak terdapat perbezaan yang signifikan $(\mathrm{p}>0.01)$ terhadap SES pelajar. 
Jadual 9

Faktor-faktor Kecerdasan Pelbagai Berdasarkan SES Menggunakan Analisis MANOVA

\begin{tabular}{lccc}
\hline \multicolumn{1}{c}{ Faktor } & F & Sig. & Eta Squared \\
\hline Muzik & 10.09 & $0.002^{*}$ & 0.020 \\
Kinestatik & 11.97 & $0.001^{*}$ & 0.024 \\
Logik Matematik & 22.08 & $0.000^{*}$ & 0.043 \\
Visual Ruang & 25.38 & $0.000^{*}$ & 0.049 \\
Verbal Linguistik & 31.58 & $0.000^{*}$ & 0.061 \\
\hline Interpersonal & 9.23 & $0.003^{*}$ & 0.018 \\
Intrapersonal & 9.65 & 0.009 & 0.014 \\
Naturalis & 3.18 & 0.075 & 0.006 \\
\hline
\end{tabular}

\section{PERBINCANGAN}

Kajian mendapati kecerdasan Visual Ruang memberi sumbangan sebanyak (97.8\%) terhadap varians dalam Logik Matematik, manakala Logik Matematik memberikan sumbangan sebanyak (44.1\%) terhadap varians Visual Ruang. Hal ini menunjukkan kecerdasan Visual Ruang dan Logik Matematik adalah saling berkait antara satu sama lain. Matematik banyak menggunakan kemahiran melibatkan penggunaan simbol, ruang, nombor dan sesuatu yang abstrak dan hal ini memerlukan kemahiran dan kecerdasan untuk menggambarkan serta menjelaskan idea abstrak dalam bentuk yang boleh difahami. Maka kecerdasan Logik Matematik seperti didefinisikan oleh Haward Gardner (1983) adalah kemahiran dalam membuat penyelesaian masalah yang kompleks, akan menjadi lebih terserlah dengan adanya sumbangan daripada kecerdasan Visual Ruang yang dapat mengesan permasalahan matematik dan menggambarkan bentuk serta ruang termasuklah mempersembahkan idea dalam bentuk grafik. Verbal Linguistik pula memberikan sumbangan sebanyak (50.2\%) ke atas varians kecerdasan Interpersonal.

Dapatan kajian ini menunjukkan bahawa melalui kecerdasan Verbal Linguistik, seseorang itu mampu meluahkan idea dan kecerdasan Interpersonal kerana ia mampu menegaskan idea kepada 
masyarakat sama seperti kemahiran berkomunikasi, maka korelasi kedua kecerdasan juga adalah satu korelasi yang kukuh (Siti Rahayah et al., 2008). Dapatan ini selari dengan kajian mengintegrasikan kemahiran berfikir dengan kemahiran berkomunikasi (Rodiah, Siti Rahayah \& Noriah, 2009). Kemahiran berkomunikasi adalah satu kemahiran yang mempunyai korelasi komunikasi dengan pemikiran manusia dan Rodiah et al. (2009) menyatakan dengan memiliki keduanya akan menjanakan pemikiran yang bermutu.

Manakala sumbangan sebanyak (22.2\%) ke atas varians kecerdasan Muzik adalah kecerdasan Verbal Linguistik. Hal ini menjelaskan bahawa pelajar sekolah yang mahir dalam menggunakan perkataan untuk menyatakan sesuatu dengan penuh perasaan adalah mereka yang dapat mengenal lagu dan membezakan rentak serta tempo dalam melodi. Selari dengan pendapat Howard Gardner (1983) yang menyatakan terdapat hubungan yang kuat antara Muzik dan emosi. Maka, seseorang akan mengeluarkan suara yang baik untuk menyanyi mengikut nada dan harmorni. Kajian juga mendapati kecerdasan Verbal Linguistik turut memberikan sumbangan sebanyak (27.9\%) terhadap varians kecerdasan Kinestatik. Kajian ke atas kelas pidato juga mendapati kecerdasan Kinestatik adalah lebih dominan daripada kecerdasan lain (Teele, 1992). Keadaan ini dapat diperhatikan apabila seseorang pelajar yang bijak berbahasa dan pandai berpidato akan menggunakan gaya badan dan ekspresi muka semasa menyampaikan sesuatu syarahan atau ucapannya. Kecerdasan Verbal Linguistik adalah kecerdasan yang dominan dimiliki dalam kalangan akademik (Siti Rahayah et al., 2004) ini adalah kerana seseorang ahli akademik menonjol dalam penggunaan bahasa, mampu meluahkan idea dan buah fikiran secara berkesan sebagaimana mereka yang pandai berpidato.

Terdapat juga kecerdasan lain yang saling memberi sumbangan iaitu (43.9\%) sumbangan terhadap varians kecerdasan Interpersonal adalah faktor kecerdasan Intrapersonal dan sebaliknya faktor kecerdasan Interpersonal memberi sumbangan sebanyak $(44.5 \%)$ terhadap varians kecerdasan Intrapersonal. Selain itu, faktor kecerdasan Interpersonal juga memberikan sumbangan sebanyak (50.2\%) terhadap varians kecerdasan Verbal Linguistik. Hal ini jelas dinyatakan oleh Gardner (1983) bahawa kecerdasan Intrapersonal adalah kebolehan pelajar untuk mengaitkan diri sendiri dengan orang lain dan menguruskan hubungan personel dengan orang lain. Menurut beliau lagi, salah satu subskala bagi kecerdasan Verbal Linguistik adalah retorik (mempengaruhi) iaitu 
menggunakan bahasa secara berkesan untuk Interpersonal dan perbincangan. Justeru, seseorang yang mempunyai kecerdasan Intrapersonal kendiri akan dapat memberikan sumbangan kepada kecerdasan Interpersonal termasuk kecerdasan Verbal Linguistik untuk berhubung dengan orang lain.

Kajian keseluruhan faktor kecerdasan pelbagai berdasarkan jantina mendapati terdapat perbezaan antara pelajar lelaki dan pelajar perempuan sebagaimana kajian Franzen (1999) dan Sook (1996). Kajian ini mendapati pelajar lelaki menunjukkan peratusan min yang lebih tinggi dalam ujian semua kecerdasan pelbagai kecuali Verbal Linguistik dan Logik Matematik. Hal ini selari dengan dapatan Siti Rahayah dan Nor Azaheen (2009) yang mendapati pelajar perempuan memiliki peratusan min lebih tinggi daripada pelajar lelaki dalam ujian pemikiran kritikal. Pemikiran kritikal banyak melibatkan kecerdasan Verbal Linguistik dan Logik Matematik. Kedua-dua fakor kecerdasan tradisi iaitu kecerdasan Logik Matematik dan Verbal Linguistik sering mendominasi kebanyakan ujian kecerdasan piawai seperti ujian IQ dan ujianujian pencapaian di semua peringkat pendidikan (Hanizah 2007; Hanizah, Siti Rahayah \& Ruhizan, 2006). Dapatan ini juga selari dengan dapatan Gardner (1993) yang menyatakan hemisfera kiri otak banyak dikuasai oleh pelajar perempuan manakala hemisfera kanan otak yang menguasai faktor Interpersonal dan Intrapersonal pula dikuasai oleh pelajar lelaki.

Terdapat perbezaan min yang signifikan dalam semua faktor kecerdasan kecuali Verbal Linguistik, Interpersonal dan Intrapersonal berdasarkan pelajar remaja perempuan dan pelajar remaja lelaki. Dapatan itu selari dengan kajian Harms (1992), yang menunjukkan terdapat perbezaan persepsi yang signifikan dalam enam daripada lapan faktor kecerdasan. Sebaliknya kajian Furnham, Hosoe dan Tang (2002), menunjukkan perbezaan signifikan dalam kecerdasan Verbal Linguistik antara jantina. Dapatan kajian penilaian kendiri ke atas pelajar universiti di Hong Kong pula menunjukkan perbezaan di antara pelajar lelaki dengan perempuan Pelajar perempuan menunjukkan penilaian kendiri paling tinggi iaitu kecerdasan interpersonal diikuti kecerdasan intrapersonal, kecerdasan verbal linguistik, kecerdasan muzik dan kecerdasan logik matematik (Chan, 2006).

Melalui min peratus kecerdasan perbagai pula menunjukkan bahawa pelajar perempuan min kecerdasan Logik Matematik dan Verbal Linguistik lebih tinggi daripada pelajar lelaki. Hal ini 
juga menjelaskan pelajar perempuan lebih ramai cemerlang dalam peperiksaan awam berbanding pelajar lelaki kerana peperiksaan awam berlandaskan pencapaian IQ sahaja. Situasi ini menyatakan bahawa pencapaian IQ hanya menguji kecerdasan Logik Matematik dan Verbal Linguistik sahaja. Manakala berdasarkan bangsa pula didapati perbezaan yang signifikan adalah hanya dalam faktor kecerdasan Muzik dan Kinestatik.

Berdasarkan kategori sekolah pula didapati terdapat perbezaan yang signifikan dalam dua faktor kecerdasan pelbagai iaitu Verbal Linguistik dan Intrapersonal antara pelajar remaja dari sekolah harian dan sekolah berasrama. Pelajar remaja di sekolah berasrama terdiri daripada pelajar terpilih berdasarkan pencapaian akademik cemerlang dalam UPSR atau PMR, maka mereka mempunyai kecerdasan Intrapersonal dan kehendak dalaman yang tinggi untuk mencapai sesuatu kejayaan. Pelajar remaja sekolah harian didapati mempamerkan min peratus yang tinggi hanya bagi faktor kecerdasan Muzik berbanding pelajar-pelajar sekolah berasrama. Pelajar remaja di sekolah berasrama pula memiliki semua min peratus yang tinggi dalam semua faktor kecerdasan pelbagai kecuali Muzik. Hal ini kerana pelajar di sekolah berasrama diasuh memiliki kemahiran sebagai seorang pemimpin. Di samping keadaan pelajar remaja sekolah berasrama yang tidak mempunyai banyak masa untuk mendengar Muzik dan berhibur, sebaliknya hanya menumpukan sepenuh perhatian pada pelajaran. Kecerdasan Muzik juga didapati rendah kerana remaja sekolah hanya ditekankan dengan keupayaan dan pencapaian intelek (IQ) atau pengajaran dan pembelajaran mereka lebih berfokus kepada peperiksaan (Siti Rahayah et al., 2004). Siti Rahayah et al. (2004) juga menyatakan kegiatan kokurikulum dalam Pendidikan Seni, Pendidikan Jasmani dan Kesihatan Muzik tidak ditekankan menjadikan salah satu sebab kecerdasan muzik pelajar rendah.

Dapatan ini selari dengan kajian kemahiran pemikiran kritikal yang menunjukkan pelajar aliran Sains adalah lebih baik berbanding aliran bukan Sains (Siti Rahayah \& Nor Azaheen, 2009). Kajian juga mendapati terdapat perbezaan signifikan dalam tujuh daripada lapan faktor kecerdasan pelbagai yang dikaji berdasarkan pelajar remaja sekolah dalam aliran Sains dan aliran bukan Sains. Dapatan ini selari dengan kajian Meers dan Wiseman (2002) yang mendapati pelajar aliran Sains dominan dalam semua faktor kecerdasan pelbagai. Menurut Hyun (2001), pelajar dari sekolah Sains memperoleh 
skor yang tinggi dalam kecerdasan Logik Matematik berbanding pelajar dalam bidang Sastera. Perbezaan yang signifikan juga didapati dalam kecerdasan Muzik, Kinestetik, Logik Matematik, Visual Ruang, Verbal Linguistik dan Interpersonal berdasarkan SES. Sebagaimana dapatan yang diperoleh dalam kajian Siti Rahayah et al. (2006) menyatakan keluarga yang mempunyai status sosioekonomi tinggi adalah memiliki kecerdasan Verbal Linguistik dan Logik Matematik yang kukuh kerana ia menjadi keperluan dalam kehidupan mereka. Oleh itu, Siti Rahayah et. al. (2004) mencadangkan agar elemen kecerdasan pelbagai perlu diterapkan dalam pengajaran dan pembelajaran di sekolah dan di institusiinstitusi pengajian tinggi, seterusnya merangka satu pentaksiran kecerdasan secara menyeluruh supaya merangkumi kesemua potensi manusia dan tidak seperti sekarang, hanya mentaksir IQ. Maka dapat disimpulkan di sini bahawa terdapat faktor-faktor kecerdasan pelbagai berdasarkan profil pelajar yang harus dikaji dan diteliti.

\section{KESIMPULAN}

Kajian tentang sumbangan lapan faktor kecerdasan pelbagai ini menjelaskan bahawa antara faktor-faktor yang dikaji saling - memberi sumbangan dan menjadi pelengkap antara satu sama lain. - Manakala kajian perbezaan faktor kecerdasan pelbagai berdasarkan jantina, bangsa, kategori sekolah, aliran dan SES pula memberikan kesedaran tentang peranan setiap faktor kecerdasan selain daripada kecerdasan Verbal Linguistik, kecerdasan Logik Matematik dan kecerdasan Visual Ruang dapat ditingkatkan.

Dapatan kajian ini juga diharap dapat meningkatkan aktiviti luar bilik darjah dalam meningkatkan kecerdasan Kinestatik dan juga aktiviti muzik. Salah satu cadangan ialah dengan melibatkan Pendidikan Seni, Pendidikan Jasmani Kesihatan dan Pendidikan Muzik dalam sistem penilaian. Maka sistem pentaksiran haruslah diperkembang supaya tidak hanya mentaksirkan kecerdasan Verbal Linguistik dan Logik Matematik semata-mata. Hal ini kerana pentaksiran bukan sahaja dapat menilai secara adil tetapi juga akan mendorong para pendidik meningkatkan dan mencungkil kecerdasan lain. Justeru, ibu bapa, sekolah dan guru perlu bersamasama berganding bahu untuk mencungkil dan meningkatkan aspek kecerdasan yang lain. 


\section{RUJUKAN}

Chan, D.W. (2006). Perceived multiple intelligences among male and female chinese gifted students in Hong Kong: The structure of the student multiple intelligence profile. ProQuest Educational Journals, 50 (4), 325-338.

Franzen, R.J. (1999). Self perception of multiple intelligences among students from middle school in the midwest (Unpublished doctoral dissertation). Universiti South Dakota.

Furnham, A., Hosoe, T., \& Tang, T.L.P. (2002). Male hubris \& female humility? Across cultural study of ratings of self, parental, and sibling multiple intelligence in America, Britain and Japan. Journal of Intelligence, 30, 101-115.

Gardner, H. (1983). Frames of mind: A theory of multiple intelligences. New York: Basic Book.

Gardner, H. (1993). Multiple intelligences: The theory in practice. New York: Basic Book.

Gardner, H., \& Hatch, T.(1989). Multiple intelligences go to school: Educational implications of the theory of multiple intelligences. Educational Reasearcher, 18(8), 4-9.

Hanizah Hamzah, Siti Rahayah Ariffin, \& Ruhizan Mohd Yasin. (2006). Girl's overachievement in the Mathematics National Examination : Can type of items be the cause? Journals of Science and Mathematics Education in Southeast Asia, 29(2).

Hanizah Hamzah. (2007). Gender-related differential item functioning (GDIF) on the Malaysia public examination (Unpublished doctoral dissertation). Fakulti Pendidikan. Universiti Kebangsaan Malaysia.

Harms, G.D. (1998). Self-perceptions of MI among selected third-, seventh- and eleventh-grade students in South Dakota (Unpublished education thesis). Universiti of South Dakota.

Hyun Jin Kim. (2001). A validation study of MI measurement (Unpublished master's thesis). South Korea National University.

Ibrahim Ahmad Bajunid. (2003). Kompetensi pelajar menghadapi pasaran pekerjaan. International Conference on Measurement and Evaluation in Education. Universiti Sains Malaysia. 5 - 7 Ogos.

Meers, G., \& Wiseman, K. (2002). Designed successful learning. The Science Teacher, 69(8), 29-31. 
Pusat Perkembangan Kurikulum. (2002a). Projek Aplikasi Teori Multiple Intelligences (PATMI). Laporan Tahunan Unit Projek Khas. Kuala Lumpur: KPM.

Reaves, C.C. 1992. Quantitative research for the behavioral sciences. New York: John Wiley and Son, Inc.

Rodiah Idris, Siti Rohayah Ariffin, \& Noriah Mohd Ishak. (2009). Pengaruh kemahiran generik dalam kemahiran pemikiran kritikal, penyelesaian masalah dan komunikasi pelajar Universiti Kebangsaan Malaysia (UKM). Malaysian Journal of Learning and Instruction (MJLI), 6, 103-140.

Spearman, C. (1904). "General intelligence" objectively determined and measured. American Journal of Psychology, 15, 201-293.

Spearman, C. (1927). Nature of intelligence and the principles of cognition. London: McMillan.

Siti Rahayah Ariffin, T. Subahan Mohd Merah, Norasmah Othman, \& Ibrahim Mohamed Zin. (2004). Analisis Kecerdasan Pelbagai (Multiple Intelligences) di kalangan pensyarah di sebuah Institusi Pengajian Tinggi (IPT). Jurnal Teknologi, 41(E), 33-42.

Siti Rahayah Ariffin, Roseni Arifin, Siti Fazriah Raja Mohamad \& Akbariah Mohd Mahdzir. (2006). Multiple intelligences: Theory and application of the rasch's model. Proceeding for Third International Conference On Measurement and Evaluation in Education (ICMEE), 287-289.

- Siti Rahayah Ariffin, Noriah Mohd Ishak, \& Abdul Ghafur Ahmad. (2006). Manual pengguna instrumen multiple intelligences. Bangi: Fakulti Pendidikan, Universiti Kebangsaan Malaysia.

Siti Rahayah Ariffin, Roseni Ariffin, \& Hafsa Mohamed Makki. (2008). Faktor kontribusi kecerdasan pelbagai dalam kalangan pelajar remaja. Jurnal Pendidikan, 33, 35-46.

Siti Rahayah Ariffin, \& Nor Azaheen Abdul Hamid. (2009). Profil kemahiran pemikiran kritikal antara pelajar aliran sains dan bukan sains. Jurnal Majlis Dekan Pendidikan Malaysia, 3, 23-36.

Soo Hee Ryue. (1996). A study on group defferences in multiple intelligences and relationships among MI, IQ and school achievement (Unpublished master's thesis). Seoul National University.

Teele, S. (1992). Teele Inventory for Multiple Intelligence (TIMI). Teacher's Manual Redlands: Sue Teele \& Associates.

Teele, S. (1997). Teele inventory for multiple intelligence (TIMI). Redlands: Sue Teele \& Associates. 